\title{
Morphology of a ferric iron-encrusted biofilm forming on the shell of a burrowing bivalve (Mollusca)
}

\author{
David C. Gillan*, Chantal De Ridder \\ Laboratoire de Biologie marine, CP 160/15, Université Libre de Bruxelles, 50 av. F. D. Roosevelt, B-1050 Bruxelles, Belgium
}

\begin{abstract}
The shell of the bivalve Montacuta ferruginosa is usually covered with a rust-coloured and ferric iron-encrusted biofilm. The latter is a structured microbial mat with 3 separate layers. The outer layer is essentially microbial (fllamentous bacteria and protozoa). The intermediary layer is both microbial and mineral (heavily ferric iron-encrusted filamentous bacteria and protozoa). The inner layer is essentially mineral (ferric iron deposits) and generally devoid of living microorganisms. The most abundant microorganisms in the biofilm are filamentous bacteria related to Beggiatoaceae. The genesis of this mineral-microbial mat could be partly due to a sequence of processes: (1) ferric iron deposition within bacterial sheaths in the outer layer; (2) the release and accumulation of heavily ferric ironencrusted sheaths after lysis of the bacteria in the intermediary layer; (3) degradation of bacterial sheaths and accumulation of ferric iron minerals in the inner layer.
\end{abstract}

KEY WORDS: Biofilm - Filamentous bacteria - Beggiatoaceae - Ferric iron - Bivalve

\section{INTRODUCTION}

Microorganisms (planktonic or sessile) colonize a wide variety of habitats in the ocean. Microbial attachment to submerged surfaces (rich in adsorbed nutrients) may lead to the further formation of a biofilm or consortium where various types of microorganisms coexist and interact (Kogure 1989, Brock et al. 1994, Cooksey \& Wigglesworth-Cooksey 1995). In a biofilm, the microorganisms are encased in extracellular polysaccharides (produced by the cells), a situation that has some nutritive and mechanical advantages - the biofilm traps nutrients from free water for its microbial population and prevents detachment of microorganisms in flowing water. Consequently, biofilms often show much greater microbial densities and activities than free water (Brock et al. 1994). A relatively thick biofilm (up to $3 \mathrm{~mm}$ in thickness) coats the shell of Montacuta ferruginosa, a small bivalve (ca $1 \mathrm{~cm}$ in length) that lives symbiotically in the burrow of an echinoid, Echinocardium cordatum (Echinodermata).

•E-mail:dgillan@ulb.ac.be
Preliminary morphological observations have shown that this biofilm is a structured microbial community where filamentous bacteria are predominant (Gillan \& De Ridder 1995). Moreover, a rust-brown ferric iron deposit is associated with the biofilm and gave the bivalve its specific name (Gage 1966).

Intimate associations of microorganisms with ferric iron deposits are widespread in nature. Such microbial communities occur in freshwater environments (bogs, lakes, springs, iron seeps, water distribution systems), in swamps and fjords, in soils and in desert rock varnishes (for a review see Ghiorse 1984). In saltwater environments, these communities occur in the pelagic zone (Cowen \& Silver 1984), in ferromanganese concretions (Burnett \& Nealson 1981) and at deep-sea hydrothermal vents (Karl et al. 1989, Juniper \& Tebo 1995). In a few cases, ferric iron-encrusted microbial communities have been found to be epibiotic on deep-sea mussel and limpet shells as well as worm tubes (Jannasch \& Wirsen 1981, Baross \& Deming 1985). Generally speaking, very little is known about the community fine structure or the specific role that these microorganisms play in iron oxidation and/or deposition. 
In this report we describe an epibiotic ferric ironencrusted microbial community associated with a shore bivalve, Montacuta ferruginosa. The aim of the present work is to characterize the morphology of the community and describe its main microbial components. The formation of the ferric iron deposit and its relationships with the bacteria are tentatively discussed.

\section{MATERIALS AND METHODS}

Collection of material. The specimens of Montacuta ferruginosa (Montagu, 1803) were collected intertidally in the burrows of Echinocardium cordatum (Pennant, 1777) (Echinoidea, Spatangoida) at Wimereux (Pas-de-Calais, France) during 1994 and 1995. Light-microscopy [bright-field and Nomarski differential interference contrast (DIC) microscopy] studies on pigments using spectrophotometry and fluorimetry, and detection of sulfur-oxidizing activity, were performed on mixed populations of microorganisms that were scraped off the bivalve shells which had previously been rinsed in sterile seawater. For electron microscopy, the coating was kept attached to the bivalves.

Stains for light microscopy. The Gram staining was carried out according to Adamse (1970). Poly$\beta$-hydroxybutyrate (PHB) granules were specifically stained with Sudan black adapting the method described in Martoja \& Martoja (1967): the samples were immersed for $15 \mathrm{~min}$ in $70 \%$ ethanol, stained with Sudan black for $15 \mathrm{~min}$, then rinsed in $70 \%$ ethanol for 1 min before being observed. Volutin granules were detected by the Neisser's stain and by metachromatic staining with aqueous toluidine blue $10.5 \%$ ) (Gurr 1963)

Detection of chlorophylls. The presence of chlorophyll and bacteriochlorophyll in bacterial filaments was investigated by spectrophotometry according to Austin (1988) and by fluorimetry. Two sets of bacteria were tested; the first was previously exposed to light for $24 \mathrm{~h}$, the other was tested directly (without incubation). The fluorimetric observations were based on the red fluorescent light emitted by the chlorophyll when it was exposed to light of 450 to $490 \mathrm{~nm}$. This was performed under a Leitz Diaplan microscope functioning in the reflected-light mode and equipped with an $12 / 3$ filter block (band pass of the excitation filter: 450 to $490 \mathrm{~nm}$; the suppression filter stops radiation under $520 \mathrm{~nm}$ ).

Elemental sulfur deposition. The ability to deposit elemental sulfur in the simultaneous presence of sulfide $\left(\mathrm{S}^{2-}\right)$ and oxygen was tested by placing the bacteria in a double gradient $\left(\mathrm{S}^{2-} / \mathrm{O}_{2}\right)$ created in $15 \mathrm{ml}$ tubes (Falcon). The gradients were prepared adapting the method described in Nelson \& Jannasch (1983): $4 \mathrm{ml}$ agar $1.5 \%-\mathrm{Na}_{2} \mathrm{~S} 8 \mathrm{mM}$ was poured onto the bottom of the tubes; $4 \mathrm{ml}$ agar $1.5 \%$ was then poured over this layer; the sterile agar medium was then covered with $4 \mathrm{ml}$ of sterile seawater. The controls contained $8 \mathrm{ml}$ agar $1.5 \%$, covered with $4 \mathrm{ml}$ of sterile seawater. Both in experimental and in control tubes, the bacteria were placed at the agar-water interface. The tubes were then capped with loose plugs and incubated at $4^{\circ} \mathrm{C}$ for $48 \mathrm{~h}$. After the incubation period, the bacteria were observed under a Nomarski microscope (DIC). The identification of sulfur granules was based on their extraction and subsequent crystalization with pyridine (Strohl \& Larkin 1978b) and on their dissolution in 95\% ethanol (Williams \& Unz 1985)

Scanning electron microscopy (SEM). Specimens of bivalves were fixed for $24 \mathrm{~h}$ either in Bouin's fluid (without acetic acid) or in 3\% glutaraldehyde in cacodylate buffer $(0.1 \mathrm{M}, \mathrm{pH} 7.4)$. The specimens fixed with glutaraldehyde were rinsed for 3 to $8 \mathrm{~d}$ in buffer, postfixed in $1 \%$ osmium tetroxide in buffer for $1 \mathrm{~h}$, then briefly rinsed in buffer. All the specimens were then dehydrated in graded ethanol $(70,90,100 \%)$, dried by the critical-point method using $\mathrm{CO}_{2}$ as transition fluid, mounted, sputter coated with gold, and viewed with a ISI DS 130 SEM microscope operating at $20 \mathrm{kV}$.

Transmission electron microscopy (TEM). For TEM specimens of bivalves were fixed with the ruthenium red-glutaraldehyde (RRG) procedure (Strohl \& Larkin 1978a). The RRG procedure was used to reveal the bacterial sheaths. The modified Ryter-Kellenberger (RK) fixation procedure was also performed (Strohl \& Larkin 1978b). This latter preserves the sulfur inclusion envelopes well (Strohl et al. 1982). After fixation, the bivalves were dehydrated in graded ethanol as for SEM. The microorganisms were then scraped away from the bivalves, immersed for $5 \mathrm{~min}$ in propylene oxide then embedded in Spurr's resin and thin sectioned (LKB ultramicrotome). Thin sections contrasted with uranyl acetate and Reynold's lead citrate were observed under a Philips EM 300 TEM microscope operating at $100 \mathrm{kV}$.

$X$-ray diffraction and energy-dispersive $X$-ray (EDAX) analyses. X-ray diffraction and EDAX analyses were done to characterize the iron precipitate of the coating. For X-ray diffraction analysis, the coatings of $3 \%$ glutaraldehyde fixed bivalves were scraped off, air-dried at ambient temperature, ground and washed with distilled water to eliminate $\mathrm{NaCl}$. After sedimentation on a glass plate and drying, the powder was placed in a diffractometer and analysed. For EDAX analysis, the bivalves were fixed with $70 \%$ ethanol, dried for $24 \mathrm{~h}$ at $60^{\circ} \mathrm{C}$ and embedded in araldite. The block obtained was sectioned, polished with silicon carbide and diamond powder (Struers) (granulometry 
of $1 \mu \mathrm{m}$ ), carbon coated and observed under a JEOL superprobe 733 SEM coupled to an EDS detector. The electron microprobe was pointed on a cross-section of the bivalve's coating. The analysis was done at $25 \mathrm{kV}$ with a sample current of $2.5 \mathrm{nA}$.

\section{RESULTS}

\section{General morphology and composition of the coating}

The mineral-microbial coating that forms on the shell of Montacuta ferruginosa (Figs. 1 \& 2) is well structured, showing 3 successive layers (Fig. 3). The inner layer is essentially made of ferric iron deposits. The intermediary layer consists of microorganisms that are heavily encrusted with ferric iron deposits. The outer layer is made of microorganisms that are poorly or non-encrusted with ferric iron deposits. The ferric iron deposits form granules whose diameter ranges from 0.05 to $1 \mu \mathrm{m}$, regardless of their location in the coating (Fig. 4). The lack of peaks in the X-ray diffraction patterns indicates that these deposits are amorphous. Microprobe analysis (EDAX) indicates that their characteristic elements are iron, phosphorus, oxygen and calcium with traces of silicon and magnesium (Fig. 5). Iron and phosphorus are similarly and homogeneously distributed throughout the coating.

The inner layer is relatively thick (up to $45 \mu \mathrm{m}$ ) and made of densely packed mineral granules that adhere to the periostracum (Figs. $3 \& 4$ ). Remains of filamentous bacteria (ferric iran-encrusted empty sheaths and extracellular material) are occasionally found. The intermediary layer is relatively thin (up to $10 \mu \mathrm{m}$ ) and consists of various types of ferric iron-encrusted microorganisms (Figs. 6 \& 7). Filamentous bacteria are predominant. Remains of lysed filaments frequently occur and are always heavily encrusted with ferric iron. Single rod-shaped bacteria are dispersed over the surface of the filamentous bacteria (Fig. 8) while microcolonies of coccoid bacteria (Fig. 9) and stalked bacteria (Fig. 10) locally occur within the layer. Dead stalked protozoans extensively covered with iron minerals are also typically seen: they correspond to 2 species of Ciliophora belonging to the Phyllopharyngea (Suctoria) (Fig. 14) and to 1 species of choanoflagellate (Fig. 15). The outer layer consists of living microorganisms that are similar to those of the intermediary layer. The filamentous bacteria are particularly abundant (Figs. 11 to 13); they extend up to $3 \mathrm{~mm}$ from the bivalve. The stalked protozoans and the filamentous bacteria are usually attached to the intermediary layer by one of their extremities; often they are partly encrusted with ferric minerals.

\section{Features of the filamentous bacteria}

The predominant members of the microbial community are filamentous bacteria. The filaments have similar lengths (ca $500 \mu \mathrm{m}$ ) and are non-motile under the light microscope. They are colourless: chlorophyll or bacteriochlorophyll are not detected, even after a 24 h exposure to light under aerobic or anaerobic conditions. The filamentous bacteria correspond to 2 morpho-physiological types that differ by the aspect of their sheath, by the morphology of their constitutive cells and by their abilities to store PHB and volutin.

Type 1 filaments (Figs. 13 \& 16 to 24). These filaments are the most abundant. They show cylindrical cells of constant diameter (5 $\mu \mathrm{m})$ (Figs. 13, 16, 18). The filaments consist of either 'long' cells (10 to $15 \mu \mathrm{m}$ in length) or 'short' cells ( 7 to $8 \mu \mathrm{m}$ in length). Rosettes are never observed. The filaments are often encrusted with ferric iron (Fig. 17), mainly at their basal part. Type 1 filaments produce a thin sheath (ca $40 \mathrm{~nm}$ thick), with a single filament per sheath (Fig. 21). Under the TEM, the sheath appears to consist of 3 separate layers, the first is situated $10 \mathrm{~nm}$ away from the cell wall (Fig. 21). The cell wall of these bacteria varies from $20 \mathrm{~nm}$ to more than $150 \mathrm{~nm}$ in thickness (Figs. 18 to 22). The filaments are Gram-variable: they are usually Gram-positive but their base (attached to the intermediary layer of the coating) is Gram-negative. Under the light microscope, 1 to 10 intracellular refringent granules may be found in each cell. These granules are up to $4.5 \mu \mathrm{m}$ in diameter (Fig. 16); most of them, particularly the wider ones, contain volutin: they are positive for Neisser's stain and are metachromatic for toluidine blue. PHB inclusions are not detected. Under the TEM, 2 inclusion types are observed: the first type (Fig. 23) is limited by a unit membrane and is generally 10 to $50 \mathrm{~nm}$ in diameter (occasionally up to $700 \mathrm{~nm}$ in diameter); the second type (Fig. 24) is limited by a collection of concentric unit membranes and is $200 \mathrm{~nm}$ in diameter. Type 1 filaments do not form light-microscope-detectable sulfur inclusions after the $48 \mathrm{~h}$ incubation with sulfide. However, rhombic crystals form close to the incubated filaments when treated with pyridine. These crystals do not form with the control filaments

Type 2 filaments (Figs. 11, 12, 25 to 31). These filaments are less abundant. They taper from the base $(2.5$ to $3.5 \mu \mathrm{m}$ in diameter) (Fig. 12) to the apex (ca $1 \mu \mathrm{m}$ in diameter) (Fig. 11). When encrusted, the filaments are 7 to $10 \mu \mathrm{m}$ in diameter (Fig. 27). Their constitutive cells are barrel-like, showing a slight narrowing at the cell junctions (Fig. 12); they are usually 1.2 to $3.5 \mu \mathrm{m}$ in length but may reach 5 to $10 \mu \mathrm{m}$ at the filament tip (Fig. 11). Particularly thick-walled and rust-brown colored cells, usually wide (up to $4 \mu \mathrm{m}$ in diameter), are 

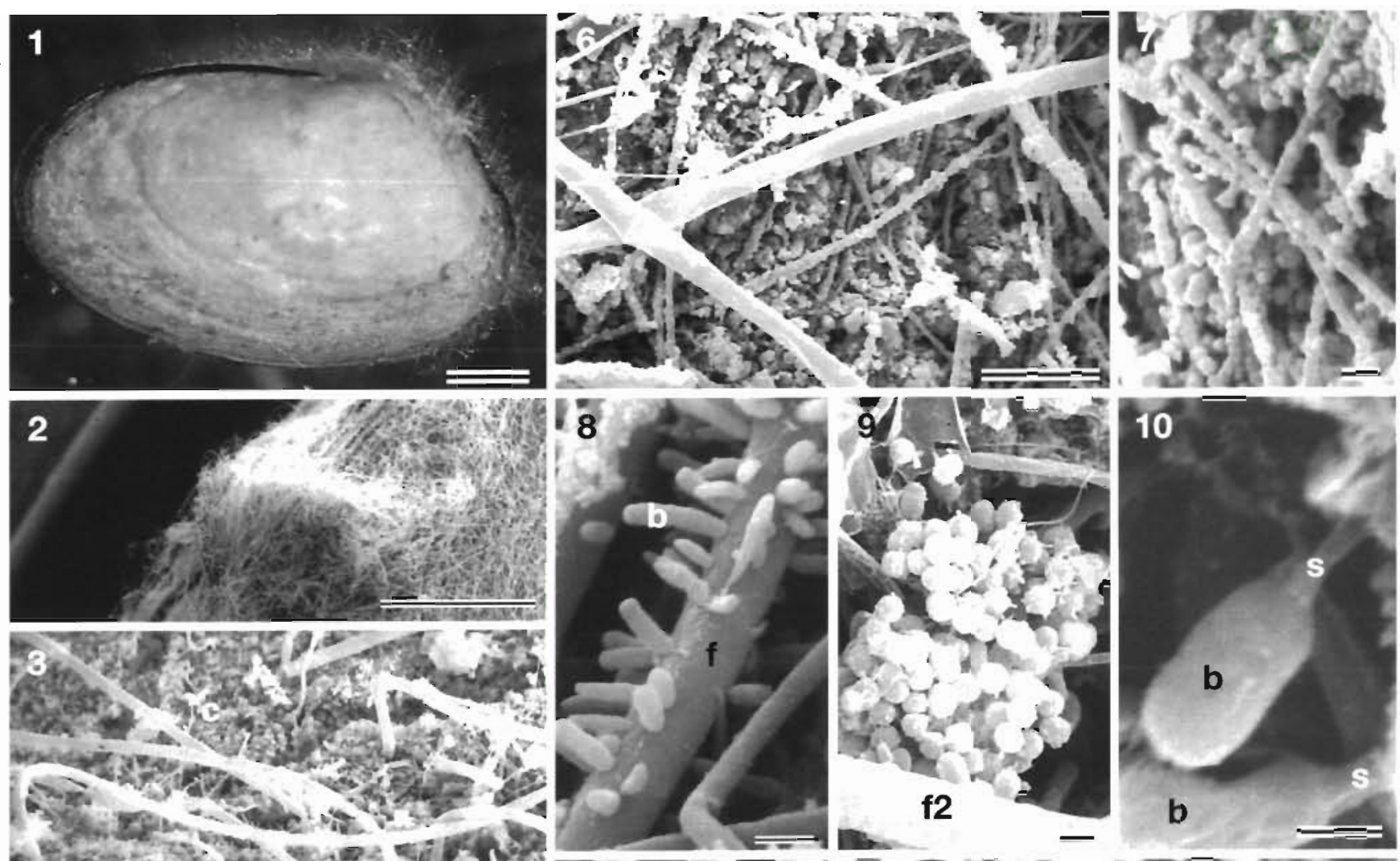

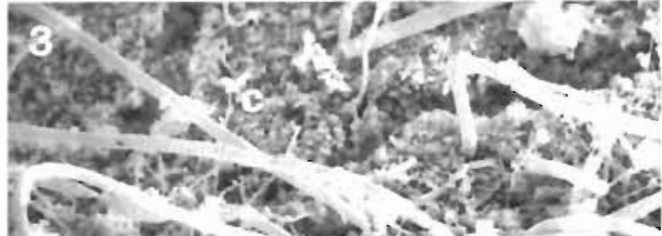

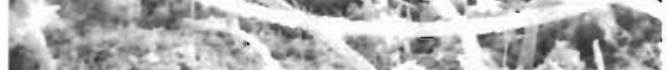
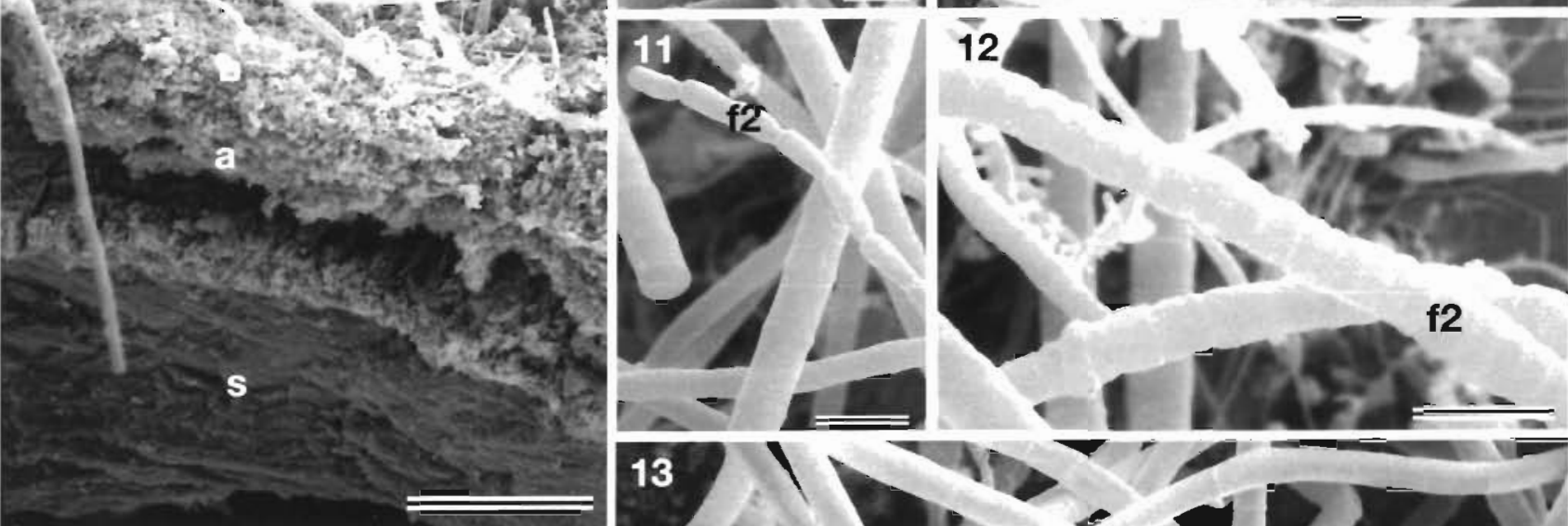

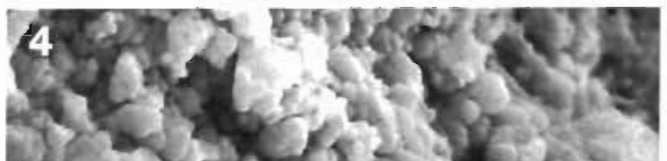

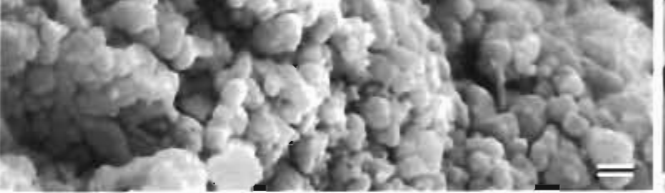
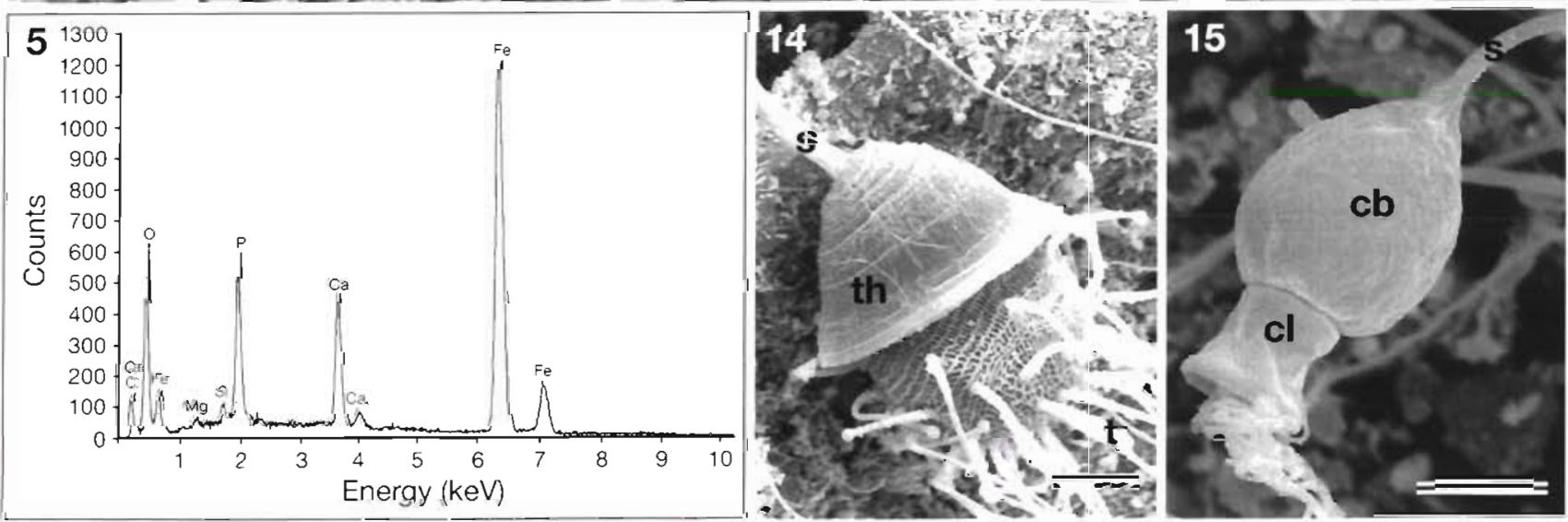
Figs. 1 to 15. Montacuta ferruginosa. Fig. 1. General view. Scale bar $=1 \mathrm{~mm}$. Fig. 2. Enlarged view of the umbo. Scanning electron microscopy (SEM). Scale bar = $1 \mathrm{~mm}$. Fig. 3. Cross-section through the coating (SEM). a: inner layer; b: intermediary layer; c: Outer layer; $\mathrm{s}$ : shell of the bivalve. Scale bar $=50 \mu \mathrm{m}$. Fig. 4 . Detailed view (cross-section) of the inner layer (SEM). Scale bar = $1 \mu \mathrm{m}$. Fig. 5. X-ray microanalysis spectra of the coating minerals. Fig. 6. Surface of the intermediary layer where bacterial filaments are progressively encrusted with ferric iron minerals (SEM). Scale bar $=20 \mu \mathrm{m}$. Fig. 7 . Surface of the intermediary layer (SEM). Scale bar $=1 \mu \mathrm{m}$. Fig. 8. Rod-shaped bacteria (b) dispersed over the surface of a bacterial filament (f) in the intermediary layer (SEM). Scale bar $=1 \mu \mathrm{m}$. Fig. 9. Microcolonies of coccoid bacteria in the intermediary layer (SEM). $\mathrm{f} 2$ : type 2 filamentous bacteria. Scale bar $=1 \mu \mathrm{m}$. Fig. 10. Stalked bacteria (b) in the intermediary layer (SEM). s: stalk. Scale bar $=0.5 \mu \mathrm{m}$. Fig. 11. Apex of a type 2 bacterial filament ( $\mathrm{f} 2$ ) in the outer layer (SEM). Scale bar $=5 \mathrm{~mm}$. Fig. 12. Type 2 bacterial filaments (f2) in the outer layer (SEM). Scale bar $=5 \mu \mathrm{m}$. Fig. 13. Type 1 bacterial filaments in the outer layer (SEM). Scale bar $=10 \mu \mathrm{m}$. Fig. 14. Ciliophora species in the outer layer (SEM). s: stalk; t: tentacles; th: theca. Scale bar $=10 \mu \mathrm{m}$. Fig. 15. Choanoflagellate species in the outer layer (SEM). cb: cellular body; cl: collar; s: stalk. Scale bar $=10 \mu \mathrm{m}$

found randomly in filaments. Rosette-like structures are occasionally formed (Fig. 26). These filaments produce a well-developed sheath (ca $200 \mathrm{~nm}$ thick), with only 1 filament per sheath (Figs. 25 \& 29); under the TEM, this sheath is adherent to the cell wall and is frequently iron-encrusted (Fig. 28). The cell wall of these bacteria is ca $20 \mathrm{~nm}$ thick (Fig. 28). The filaments are Gram-negative. Under the light microscope, numerous intracellular refringent granules (up to $500 \mathrm{~nm}$ in diameter) are observed (Fig. 25). Some contain PHB (sudanophilic reaction) and others volutin. Under the TEM, 3 inclusion types are observed (Figs. 28 \& 30): the first and the second type are not limited by a membrane and may reach $200 \mathrm{~nm}$ in diameter; the first type is electron-transparent, the second is electron-dense. The third inclusion type reaches $100 \mathrm{~nm}$ in diameter. It is limited by a unit membrane often continuous with the cytoplasmic membrane and is weakly electrondense. The filaments are able to form light-microscopedetectable intracellular sulfur granules (up to $300 \mathrm{~nm}$ in diameter) when they are exposed to sulfide for $48 \mathrm{~h}$ (Fig 31). These granules are extracted with pyridine and $95 \%$ ethanol. With pyridine, crystals form outside the filaments. These crystals do not form with the control filaments.

\section{DISCUSSION}

The occurrence of a biofilm on the shell of Montacuta ferruginosa is not surprising because all surfaces immersed in seawater are readily colonised by a variety of microorganisms (Kogure 1989, Cooksey \& Wigglesworth-Cooksey 1995). However, the structure of this biofilm is unique: it forms a thick mat that is deeply ferric iron-encrusted and made essentially of filamentous bacteria. The mat forming on the shell of $M$. ferruginosa is 3-layered, comprising a microbial outer layer and a mineral inner layer separated by a mixed intermediary layer. This microbial mat presents a similar organisation to the mat covering mussels at the Galapa- gos Rift (Jannash \& Wirsen 1981, Jannash 1984): both of them are deeply encrusted and do not feature a lot of cell layers, so they are very different from stromatolitic structures. The mineral component of the mat covering M. ferruginosa probably consists of amorphous ferric phosphates: phosphorus is one of the predominant elements detected in the coating minerals, along with iron and oxygen; infrared absorption studies (D. C. Gillan unpubl. data) indicate the presence of phosphate. Bacterial mats encrusted with amorphous ferric minerals rich in phosphorus are also known to occur in some hydrothermal vent fields (Karl et al. 1989).

The filamentous bacteria of this ferric iron-encrusted consortium belong to 2 major morphotypes: thinsheathed filaments with cylindrical cells (morphotype 1) and thick-sheathed filaments with barrel-like cells (morphotype 2). Both morphotypes present key traits of the Beggiatoaceae (Strohl 1989): they grow as filaments (cells attached end-to-end), they never form chlorophyll and they are able to store sulfur in the presence of sulfide. A key trait of the Beggiatoaceae not detected here is gliding motion of the filaments. The sulfur-oxidizing ability appears somewhat different according to the bacterial morphotype. In morpholype 1, light-microscope-detectable inclusions are not formed when the filaments are exposed to sulfide (i.e. when they are placed in a double gradient $\mathrm{S}^{2-} / \mathrm{O}_{2}$ ). Morphotype 1 filaments appear, however, able to store intracellular sulfur: sulfur is extracted from the filaments when they are treated with pyridine (formation of external rhombic crystals). In contrast, morphotype 2 is clearly a sulfur-oxidizer: light-microscopedetectable inclusions of elemental sulfur are formed when the filaments are exposed to sulfide, these inclusions disappear with pyridine or ethanol, and extracellular rhombic crystals form close to the filaments when they are treated with pyridine. Both morphotypes observed in thin sections have unit membranelimited inclusions that are known to typically contain sulfur in Beggiatoaceae (Bland \& Staley 1978, Strohl et al. 1981, 1982). These inclusions are neither PHB 


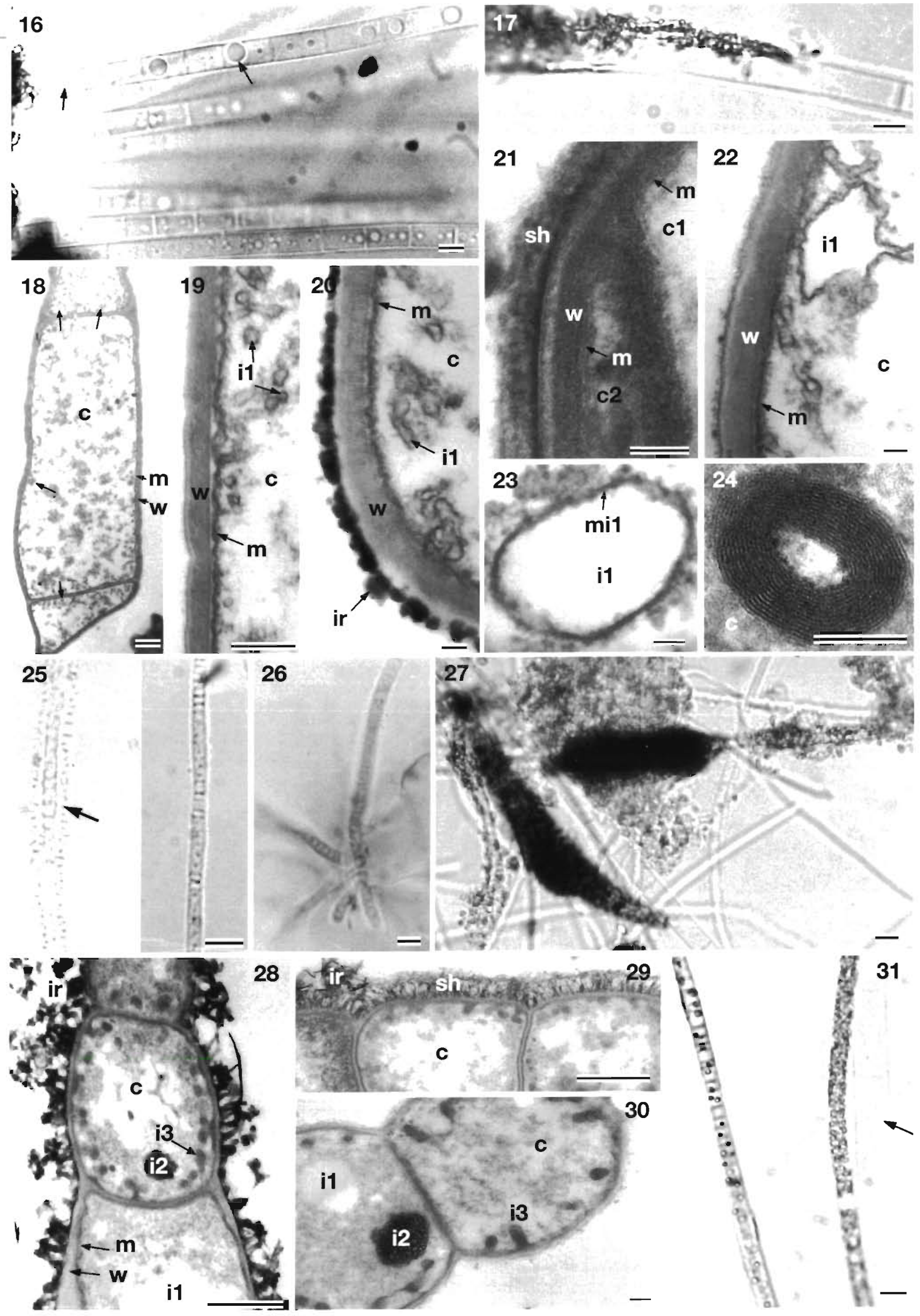


Figs. 16 to 31. Montacuta ferruginosa. Fig. 16. Type 1 filaments with intracellular refrungent granules (arrows). Differential interference contrast (DIC) microscopy. Scale bar $=5 \mu \mathrm{m}$. Fig. 17. Type 1 filaments encrusted with ferric iron minerals (DIC). Scale bar $=5 \mu \mathrm{m}$. Fig. 18. Type 1 filament. Arrows point to small type 1 inclusions (transmission electron microscopy, TEM). c: cytoplasm; $\mathrm{m}$ : cell membrane; w: cell wall. Scale bar $=1 \mu \mathrm{m}$. Fig. 19. Type 1 filament (enlarged view of Fig. 18) (TEM). c: cytoplasm; i1: type 1 inclusions; m: cell membrane; w: cell wall. Scale bar $=50 \mathrm{~nm}$. Fig. 20. Type 1 filament with a ferric iron-encrusted sheath (TEM) c: cytoplasm; i1: type 1 inclusions; ir: iron oxıde; m: cell membrane; w: cell wall. Scale bar $=100 \mathrm{~nm}$. Fig. 21 . Type $1 \mathrm{fjlament}$ with a sheath (sh) revealed by ruthenium red (TEM). c1, c2: 2 adjoining cells; $\mathrm{m}$ : cell membrane; w: cell wall. Scale bar $=50$ nm. Fig. 22. Type 1 filament with a large type 1 inclusion (1) (TEM). c: cytoplasm; $\mathrm{m}$ : cell membrane; w: cell wall. Scale bar $=100 \mathrm{~nm}$. Fig. 23. Enlarged view of type 1 inclusion (i1) inside a type 1 filament (TEM). c: cytoplasm; mi1: membrane of the type 1 inclusion. Scale bar $=100 \mathrm{~nm}$. Fig. 24. Enlarged view of a type 2 inclusion inside a type 1 filament (TEM). c: cytoplasm. Scale bar $=100 \mathrm{~nm}$. Fig. 25. Type 2 filaments (DlC). Arrow points to a sheathed filament. Scale bar $=5 \mu \mathrm{m}$. Fig. 26 . Type 2 filaments forming a rosettelike structure (DIC). Scale bar $=5 \mu \mathrm{m}$. Fig. 27. Type 2 filaments encrusted with ferric iron minerals (DIC). Scale bar $=5 \mu \mathrm{m}$. Fig. 28 Type 2 filament with a ferric iron-encrusted sheath (TEM). c: cytoplasm; i1, i2, i3: inclusions of types 1, 2 and 3; ir ferric iron; m: cell membrane; w: cell wall. Scale bar $=500 \mathrm{~nm}$. Fig. 29. Type 2 filament with a sheath (sh) revealed by ruthenium red (TEM). c: cytoplasm; ir: ferric iron. Scale bar $=500 \mathrm{~nm}$. Fig. 30. Type 2 filament (TEM). c: cytoplasm; i1, i2, i3: inclusions of types 1, 2 and 3. Scale bar $=100 \mathrm{~nm}$. Fig. 31. Type 2 filaments showing intracellular sulfur granules after exposure to sulfide. Arrow points to a type 1 filament (DIC). Scale bar $=5 \mu \mathrm{m}$

(PHB inclusions are limited by a non-unit membrane) nor volutin (volutin inclusions are not membrane-limited) (Shively 1974). Although the 2 morphotypes share several morpho-physiological features, their general morphology and ultrastructure (under identical fixation and staining procedures) suggest they do not belong to the same species. With regard to this last point, morphotype 1 possesses a maximum of 4 electron-dense layers external to the cytoplasmic membrane (the first layer, close to the cytoplasmic membrane, is the thick wall; the second layer, aherent to the sheath could represent the outer membrane of the wall; the last 2 layers are in the sheath) whereas morphotype 2 possesses 2 electron-dense layers external to the cytoplasmic membrane (one is the outer membrane, the other the sheath).

Morphotypes 1 and 2 share some morpho-physiological features with the genera Beggiatoa and Thiothrix, respectively:

Morphotype 1 and Beggiatoa have in common their general dimensions (cylindrical cells), the presence of a poorly developed sheath, the presence of inclusions limited by several concentric unit membranes and the ability to store volutin (Strohl et al. 1982, Strohl 1989). However, morphotype 1 differs from Beggiatoa by its Gram staining (Beggiatoa is Gram-negative), by its cell wall sometimes being very thick (accounting likely for the Gram-positive reaction along the major part of the filaments) and by the apparent absence of PHB. In addition, the envelope (wall and sheath) architecture of morphotype 1 differs from that of previous studies on Beggiatoa spp. (Maier \& Murray 1965, Strohl et al. 1982).

Morphotype 2 presents features of the genus Thiothrix, i.e. a relatively narrow diameter (1 to $3.5 \mu \mathrm{m}$ ), the presence of a well-developed sheath, the occurrence of 1 filament per sheath, the differentiation into a basal and apical region (Winogradsky 1949, Bland \& Staley
1978, Larkin 1980, Strohl 1989). As is Thiothrix, morphotype 2 is able to store volutin and PHB. However, the ability to form rosettes is doubtful (the rosette-like structure of Fig. 26 was only observed once and the contact point of the filaments was not clearly resolved). In addition, the envelope architecture of morphotype 2 is somewhat different from that of Thiothrix depicted by Williams et al. (1987) in that no intensely staining layer corresponding to the peptidoglycan layer has been detected in the wall (the cytoplasmic and outer membrane of the cell wall are separated by an almost clear regionj. The general morphology and envelope structure of morphotype 2 are also very different from those of Thiothrix-like bacteria occurring in mats around subtidal hydrothermal vents (Jacq et al. 1989). Although the 2 morphotypes both present key traits found in the Beggiatoaceae, their taxonomic position remains tentative (molecular studies in progress should clarify the situation).

It is worth noting that heavy metal-encrusted microbial communities featuring Beggiatoa- and Thiothrixlike filaments were also observed at the Galapagos Rift vent site (Jannasch \& Wirsen 1981), but the ultrastructure of the filaments was not studied in detail so direct comparisons cannot be made. The filamentous morphotypes of Montacuta ferruginosa appear different from those described in other deep-sea heavy metalencrusted microbial communities, at the Loihi Seamount (Karl et al. 1989) or at Juan de Fuca Ridge (Juniper et al. 1995)

The filamentous bacteria of Montacuta ferruginosa contain amorphous ferric iron minerals in their sheaths, but the processes leading to this accumulation were not studied here. According to the literature, several pathways can lead to the accumulation of ferric iron within bacterial sheaths. They can be summarized as follows: 
(1) Though pure forms are rare, colloidal oxyhydroxides featuring iron occur in seawater (Wells et al. 1995). Bacteria could passively accumulate iron colloids in their anionic exopolymeric substances (EPS) (sheath, capsule) if the colloids are positively charged (Macrae \& Edwards 1972). In this (bio)accumulation process, the bacteria are not involved in the mineralization.

(2) Free ionic iron species [ferrous ions, ferric ions, and the hydrolysis products $\left.\mathrm{Fe}(\mathrm{OH})_{2}{ }^{+}, \mathrm{Fe}(\mathrm{OH})_{4}{ }^{-}\right]$are very scarce in oxic seawater $\left(10^{-8}\right.$ to $10^{-10} \mathrm{M}$ ) (Wells et al. 1995). Bacteria may directly accumulate the iron cations in their EPS. They may also oxidize ferrous ions then accumulate the resulting ferric ions. Such an oxidation may be indirect (induced by a redox modification of the medium due to the excretion of molecules stemming from the general metabolism of the bacteria) or direct (due to the presence of an extracellular ironoxidizing enzyme, as with Leptothrix discophora; Corstjens et al. 1992).

(3) Insoluble ferric minerals could also be accumulated extracellularly by the microbial degradation of ferric ion chelates such as siderophores and other organic complexes (Dahanayake \& Krumbein 1986, Ehrlich 1990).

In these last 2 processes, the deposition of ferric iron minerals on bacteria may be considered as a biomineralization process (Lowenstam \& Weiner 1983) as the bacteria contribute to the formation of the minerals. Interactions between bacteria and iron are numerous and reviewed in detail elsewhere (Brierley et al. 1989, Ferris 1989, Geesey \& Jang 1989, Ehrlich 1990). In addition, once initiated by the bacteria (passively or actively), the precipitation of ferric iron minerals in EPS could go further through nucleation as described for iron phosphates (Dalas 1990).

The simple presence of deposited oxidized iron on the epibiotic microorganisms of Montacuta ferruginosa cannot be taken as diagnostic for any of the above accumulation pathways, so it is at present not known if we are faced with bioaccumulation, biomineralisation or both processes. However, knowing that the EPS of microorganisms readily bind a variety of metals (McLean et al. 1996) and that Fe(III)-oxyhydroxide coatings readily and irreversibly bind bacterial cells (Mills et al. 1994), 3 complementary processes could at least partly explain the accumulation of ferric iron minerals on the bivalve: (1) the deposition of ferric iron within bacterial EPS in the outer layer, (2) the accumulation of heavily ferric iron-encrusted bacteria would form the intermediary layer, (3) the degradation of the bacteria and EPS would lead to the subsequent accumulation of the ferric iron minerals, forming the inner layer. Microorganisms and ferric iron granules, in a very thin ferric iron-encrusted biofilm, are found on very young bivalves. This last observation shows that bacteria are always present and that the 3 step process could take place throughout the life of the bivalves, until a thick mat with an almost mineral inner layer is formed.

The simultaneous presence of ferric iron minerals and sulfide oxidizing bacteria is interesting: the oxidation of sulfur compounds by bacteria produces a lowering of the $\mathrm{pH}$ (Brock et al. 1994) that might dissolve the ferric iron minerals that are deposited in the biofilm. In addition, some sulfur-oxidizing bacteria are able to use oxidized iron as an external electron acceptor in metabolism (Lovley 1991); this dissimilatory iron reduction process also dissolves the ferric iron minerals. Such a process could occur in anaerobic regions of the biofilm with the subsequent production of soluble ferrous iron. On the other hand, the hypothesis has been advanced that a low $\mathrm{pH}$ within sheaths, generated by sulfur oxidation, might enable some bacteria to profit from an energy-yielding iron oxidation (Jannasch 1984); in this last process, the soluble ferrous ions are consumed and a ferric iron deposit precipitates. Although they were not demonstrated, one may tentatively suggest the existence of the above processes; they would lead to the creation of a localized iron cycle within the biofilm, as suggested for the ferric iron-encrusted biofilm described by Emerson \& Revsbech (1994)

The presence of sulfide in the environment is also interesting if Montacuta ferruginosa is periodically exposed to sulfide, the ferric iron minerals of the biofilm are expected to be reduced to black ferrous sulphide. Although in the field the bivalves were always found coated with a rust-coloured deposit, under experimental conditions $M$. ferruginosa blackens after exposure to sulfide, a situation similar to Halicryptus spinulosus (Oeschger \& Vetter 1992). Actually, $M$. ferruginosa possesses the nearly complete peripheral system of sulfide defense mechanisms described by Vismann (1991): a shell, ferric iron deposits, ectosymbionts and water flow over its body (see below).

The characterization of microbial communities existing at sites where active iron deposition occurs is important for geochemists as models for understanding the biogeochemical processes that lead to iron or manganese ore deposition (Emerson \& Revsbech 1994). In that context, the microbial mat occurring on Montacuta ferruginosa could be compared to a type of biolaminated particle, i.e. an oncoid, as described by Dahanayake \& Krumbein (1986) and Gerdes \& Krumbein (1987). These authors define an oncoid as a single laminated particle that is of biogenic origin and whose diameter exceeds $2 \mathrm{~mm}$. They mention in particular that biolaminated deposits (structures and particles) consisting of microbial or fungal mats are observed in 
iron formations from early Proterozoic to modern ages. They also interestingly infer paleoenvironmental data from the comparative study of fossil and present-day biolaminated deposits. With regard to this question, it is appropriate to note that the environment of $M$. ferruginosa is rather particular The bivalve lives in the burrow of Echinocardium cordatum that is located up to $20 \mathrm{~cm}$ deep in medium to fine-grained sediments. The burrow is connected to the sediment surface via a vertical tube and is the source of oxygenated weak water currents due to the echinoid ciliature (FosterSmith 1978). The bivalve usually lies behind the echinoid in a tubular extension of the burrow that is called the sanitary drain. In this location, the bivalve is exposed to weak water currents that simultaneously carry oxygen and waste products (i.e. the echinoid faeces). In this location $M$. ferruginosa is presumably exposed to 2 independent sources of ferrous iron, i.e. the deep anoxic sediments located beneath the redox potential discontinuity layer (RPD) as suggested by Gage (1966) and the faeces produced by the echinoid (Gillan \& De Ridder 1995). Actually, the faeces of E. cordatum consist of reduced sediments (De Ridder \& Jangoux 1985) and seemingly contain ferrous ions (Buchanan et al. 1980).

Acknowledgements. The authors thank Drs A. Preat and A. Bernard for the diffractometer and EDS analysis, Dr R. L. Brigmon for helpful advice, W. Dereck for technical assistance in electron microscopy and R. Gillan for scanning photographs. Research supported by a FRIA grant to D.G. (ref. 940733) and a FRFC grant to C.D.R. (ref. 2-4510-96). Contribution of the 'Centre Interuniversitaire de Biologie Marine' (CIBIM)

\section{LITERATURE CITED}

Adamse AD (1970) Some characteristics of arthrobacters from a dairy waste activated sludge. Water Res 4:797-803

Austin B (ed) (1988) Methods in aquatic bacteriology. $J$ Wiley \& Sons, Chichester

Baross JA, Deming JW (1985) The role of bacteria in the ecology of black-smoker environments. Bull Biol Soc Wash 6:355-371

Bland JA, Staley JT (1978) Observations on the biology of Thiothrix. Arch Microbiol 117:79-87

Brierley CL, Brierley JA, Davidson MS (1989) Applied microbial processes for metals recovery and removal from wastewater. In: Beveridge TJ, Doyle RJ (eds) Metal ions and bacteria. J Wiley \& Sons, New York, p 359-382

Brock TD, Madigan MT, Martinko JM, Parker J (eds) (1994) Biology of microorganisms. Prentice-Hall International, Englewood Cliffs

Buchanan JB, Brown BE, Coombs TL, Pirie BJS, Allen JA (1980) The accumulation of ferric iron in the guts of some spatangoid echinoderms. J Mar Biol Ass UK 60:631-640

Burnett BR, Nealson KH (1981) Organic films and microorganisms associated with manganese nodules. Deep Sea Res 28A.(6):637-645
Cooksey KE, Wigglesworth-Cooksey B (1995) Adhesion of bacteria and diatoms to surfaces in the sea: a review. Aquat Microb Ecol 9:87-96

Corstjens PLAM, De Vrind JPM. Westbroek P, De Vrind-De Jong EW (1992) Enzymatic iron oxidation by Leptothrix discophora: identification of an iron-oxidizing protein. Appl Environ Microbiol 58:450-454

Cowen JP, Silver MW (1984) The association of iron and manganese with bacteria on marıne macroparticulate material. Science 224:1340-1342

Dahanayake K, Krumbein WE (1986) Microbial structures in oolitic iron formations. Miner Deposita 21:85-94

Dalas E (1990) Overgrowth of iron (III) phosphate on collagen J Chem Soc Faraday Trans 86:2967-2970

De Ridder C, Jangoux $M$ (1985) Origine des sédiments ingérés et durée du transit digestif chez l'oursin spatangide, Echinocardium cordatum (Pennant) (Echinodermata). Annls Inst Océanogr Paris 6:51-58

Ehrlich HL (1990) Geomicrobiology of iron. In: Ehrlich HL (ed) Geomicrobiology, 2nd edn. Marcel Dekker Inc, New York, p 283-346

Emerson D, Revsbech NP (1994) Investigation of an ironoxidizing microbial mat community located near Aarhus, Denmark: field studies. Appl Environ Microbiol 60: 4022-4031

Ferris FG (1989) Metallic ion interactions with the outer membrane of Gram-negative bacteria. In: Beveridge TJ, Doyle RJ (eds) Metal ions and bacteria. J Wiley \& Sons, New York, p 295-323

Foster-Smith RL (1978) An analysis of water flow in tubeliving animals. J Exp Mar Biol Ecol 34:73-95

Gage J (1966) Observations on the bivalves Montacuta substriata and $M$. ferruginosa, 'commensals' with spatangoids. J Mar Biol Ass UK 46:49-70

Geesey GG, Jang L (1989) Interactions between metal ions and capsular polymers. In: Beveridge TJ, Doyle RJ (eds) Metal ions and bacteria. J Wiley \& Sons, New York, p 325-357

Gerdes G, Krumbein WE (1987) Biolaminated deposits. Lecture notes in earth sciences no. 9; Bhattacharji S, Friedman GM, Neugebauer HJ, Seilacher A (eds). Springer-Verlag, Berlin

Ghiorse WC (1984) Biology of iron- and manganese-depositing bactena. Ann Rev Microbiol 38:515-550

Gillan DC, De Ridder C (1995) The microbial community associated with Montacuta ferruginosa, a commensal bivalve of the echinoid Echinocardium cordatum. In: Emson $\mathrm{RH}_{\text {, }}$ Smith AB, Campbell AC (eds) Echinoderm research 1995 Balkema, Rotterdam, p 71-76

Gurr GT (ed) (1963) Biological staining methods, 7th edn. GT Gurr Ltd, London

Jacq E, Prieur D, Nichols P, White DC, Porter T, Geesey GG (1989) Microscopic examination and fatty acid characterization of filamentous bacteria colonizing substrata around subtidal hydrothermal vents. Arch Microbiol 152:64-71

Jannasch HW (1984) Chemosynthetic microbial mats of deepsea hydrothermal vents. In: Cohen Y, Castenholz RW, Halvorson $\mathrm{HO}$ (eds) Microbial mats: stromatolites. Alan R Liss, New York, p 121-131

Jannasch HW, Wirsen CO (1981) Morphological survey of microbial mats near deep-sea thermal vents. Appl Environ Microbiol 41:528-538

Juniper SK, Martineu P, Sarrazin J, Gélinas Y (1995) Microbial-mineral floc associated with nascent hydrothermal activity on CoAxial Segment, Juan de Fuca Ridge. Geophys Res Lett 22:179-182

Juniper SK, Tebo BM (1995) Microbe-metal interactions and mineral deposition at hydrothermal vents. In: Karl DM (ed) 
The microbiology of deep-sea hydrothermal vents. CRC Press, New York, p 219-253

Karl DM, Brittain AM, Tilbrook BD (1989) Hydrothermal and microbial processes at Loihi Seamount, a mid-plate hotspot volcano. Deep Sea Res 36:1655-1673

Kogure K (1989) Attachment of aquatic bacteria - overview. In Hattori T et al. (eds) Recent advances in microbial ecology. Proc 5th Int Symp on Microbial Ecology, p 131-134

Larkin JM (1980) Isolation of Thiothrix in pure culture and observation of a filamentous epiphyte on Thiothrix. Curr Microbiol 4:155-158

Lovley DR (1991) Dissimilatory Fe(III) and Mn(IV) reduction Microbiol Rev 55:259-287

Lowenstam HA, Weiner S (1983) Mineralisation by organisms and the evolution of biomineralisation. In: Westbroek $\mathrm{P}, \mathrm{De}$ Jong EW (eds) Biomineralisation and biological metal accumulation. D Reidel Publishing Co, Dordrecht, p 191-203

Macrae IC, Edwards JF (1972) Adsorption of colloidal iron by bacteria. Appl Microbiol 24:819-823

Maier S, Murray RGE (1965) The fine structure of Thioploca ingrica and a comparison with Beggiatoa. Can J Microbiol 11:645-663

Martoja R, Martoja M (1967) Initiation aux techniques de l'histologie animale. Masson \& Cie, Paris

Mclean RJC, Fortin D, Brown DA (1996) Microbial metalbinding mechanisms and their relation to nuclear waste disposal. Can J Microbiol 42:392-400

Mills AL, Herman JS, Hornberger GM, DeJesus TH (1994) Effect of solution ionic strength and iron coatings on mineral grains on the sorption of bacterial cells to quartz sand. Appl Environ Microbiol 60:3300-3306

Nelson DC, Jannasch HW (1983) Chemoautotrophic growth of a marine Beggiatoa in sulfide-gradient cultures. Arch Microbiol 136:262-269

Responsible Subject Editor: F. Rassoulzadegan, Villefranche-sur-Mer, France
Oeschger R, Vetter RD (1992) Sulfide detoxification and tolerance in Halicryptus spinulosus (Priapulida): a multiple strategy. Mar Ecol Prog Ser 86:167-179

Shively JM (1974) Inclusion bodies of prokaryotes. Ann Rev Microbiol 28:167-187

Strohl WR (1989) Beggiatoales Buchanan 1957 In: Staley JT (ed) Bergey's manual of systematic bacteriology. Vol 3 Williams \& Wilkins, Baltimore, MD, p 2089-2110

Strohl WR, Geffers I, Larkin JM (1981) Structure of the sulfur inclusion envelopes from four Beggiatoas. Curr Microbiol $6: 75-79$

Strohl WR, Howard KS, Larkin JM (1982) Ultrastructure of Beggiatoa alba strain B15LD. J Gen Microbiol 128 : $73-84$

Strohl WR, Larkin JM (1978a) Cell division and trichome breakage in Beggiatoa. Curr Microbiol 1:151-155

Strohl WR, Larkin JM (1978b) Enumeration, isolation, and characterization of Beggiatoa from freshwater sediments. Appl Environ Microbiol 36:755-770

Vismann B (1991) Sulfide tolerance: physiological mechanisms and ecological implications. Ophelia 34:1-27

Wells ML, Price NM, Bruland KW (1995) Iron chemistry in seawater and its relationship to phytoplankton: a workshop report. Mar Chem 48:157-182

Williams TM, Unz RF (1985) Isolation and characterisation of filamentous bacteria present in bulking activated sludge Appl Microbiol Biotechnol 22:273-282

Williams TM, Unz RF, Doman JT (1987) Ultrastructure of Thiothrix spp. and 'Type $\mathrm{O} 21 \mathrm{~N}$ ' bacteria. Appl Environ Microbiol 53:1560-1570

Winogradsky S (1949) Contribution à la morphologie et physiologie des sulfobactéries. In: Editeurs Libraires de l'Académie de Médecine (eds) Microbiologie du sol. Masson \& Cie, Paris, p 83-126

Manuscript first received: March 29, 1996

Revised version accepted: October 14, 1996 